\title{
MICRO BUSINESS DEVELOPMENT STRATEGY TO OPTIMIZE BUSINESS LOCATIONS CULINARY TOURISM AREA
}

\author{
Priska Shirty Thelma Mawuntu \& Reynaldo Christian Aotama \\ Fakultas Ekonomi, Universitas Sariputra Indonesia Tomohon, \\ Tomohon, Indonesia
}

\begin{abstract}
This study aims to identify and analyze the factors that influence the appropriate alternative strategies, and priority strategies for the development of micro businesses in the culinary tourism area. This research uses descriptive qualitative method by collecting data through interviews. Data were analyzed using three stages of strategy formulation: input stage, matching stage, and decision stage. This study found that the factors that influence the development of micro businesses in culinary tourism areas are varied products, low managerial ability of business owners, technological and information development, and changes in lifestyle and people's interest in culinary products. Second, appropriate alternative strategies are to increase production capacity, maintain affordable product prices, provide adequate supporting facilities, take management training for business owners, conduct simple financial records, increase marketing through digital marketing, collaborate with suppliers of raw materials, and improve product quality and innovation. Third, a priority strategy in developing micro businesses in the culinary tourism area is to improve product quality and innovation.
\end{abstract}

Keywords: micro business, travel, culinary, development strategy, product innovation

\section{INTRODUCTION}

Micro, Small and Medium Enterprises (MSMEs) are the backbone of the popular economic system and they have a very important role for the Indonesian economy. The contribution of MSMEs in employment, the formation of Gross Domestic Product (GDP), equitable distribution of development results, and poverty alleviation in Indonesia are real examples of contributions from Micro, Small and Medium Enterprises (MSMEs).

In 2013, MSMEs contributed 57.56 percent to the National Gross Domestic Product (GDP) and increased employment rates by 96.99 percent of the total workforce in Indonesia. MSMEs also make a large contribution to na- tional foreign exchange through non-oil and gas exports 15.68 percent of the total value of national non-oil and gas exports (Ministry of Cooperatives and MSMEs, 2013).

MSME is one of the driving forces to improve the national and regional economy. Therefore, UMKM must be developed continuously. The culinary industry is one of the businesses that are in great demand by the people of Indonesia and this industry has contributed significantly to the Indonesian economy. Based on data from the Survey of the Creative Economy Agency (Bekraf) and BPS, the culinary subsector has dominated the creative economy sector by contributing to the GDP of $41.69 \%$ of the total GDP of the creative economy in 2015 .

\footnotetext{
*Corresponding Author.

e-mail: priska.mawuntu@gmail.com

https://doi.org/10.37715/jee.v8i2.1119
} 
Priska Shirty T.M. \& Reynaldo C.A. / Micro Business Development Strategy to Optimize Business Locations Culinary Tourism Area / JEE, Vol. 7, No. 2, September 2019, pp 41-50

The contribution is equal to Rp. 852.24 trillion (Indonesian Creative Economy Agency, 2017).

To develop a culinary business, business people must run innovation and creativity. Therefore, choosing the right strategy is needed. In determining the right strategy, the government and related parties must have a clear reference: the factors that influence the performance of micro businesses both internal and external factors. The right business development strategy is expected to make the MSME empowerment program more effectively and on target.

This study aims to analyze the internal and external factors that influence the development of micro businesses in culinary tourism areas, formulate appropriate alternative strategies, and identify strategies that must be prioritized for developing micro businesses.

\section{METHOD}

This research uses a qualitative approach. This method is used to provide a true picture of the situation of microenterprise in the culinary tourism area of Tomohon City, North Sulawesi Province, Indonesia. In addition, this study aims to explore both internal and external factors that affect the performance of micro businesses in the culinary tourism area, and formulate alternative strategies to develop these micro businesses.

The data analysis technique used in this study is a business environment analysis technique with three stages of strategy formulation, namely the input stage, matching stage and decision stage (David, 2011). Internal Factor Evaluation (IFE) matrix, External Factor Evaluation (EFE) matrix, SWOT analysis and Quantitative Strategy Planning Matrix (QSPM) are the analytical tools of this study.
At the input stage, information is collected to identify internal and external factors of microbusiness using the IFE (Internal Factors Evaluation) matrix and EFE (External Factors Evaluation) matrix. Each factor is then weighted between 0.0 (not important) to 1.0 (very important) based on the relative importance of each factor to the success of the business. Furthermore, a rating of 1 to 4 is given for each factor. In the IFE matrix, a rating is also given to the business profile. For example, a value of 4 is given to major strengths, 3 for minor strengths, 2 for minor weaknesses, and 1 for major weaknesses. Related to the EFE matrix, the rating is given based on the effectiveness of the micro business strategy which is temporarily carried out in response to external strategic factors. A value of 4 will be given to the factor if the strategy is able to respond very well to the opportunities and threats that exist. A value of 3 is if the response is good or above average. A value of 2 is given to the factor if the response is considered sufficient. A value of 1 is given if the response to opportunities and threats is not good.

In the matching stage, this study uses a SWOT matrix analysis tool that aims to systematically determine the right alternative strategy for the development of micro businesses in the Tomohon City culinary tourism area. The strategy is expected to maximize strengths and opportunities while minimizing weaknesses and threats. This matrix produces four types of strategies, the S-O strategy, which is a strategy to optimize the power to seize opportunities. W-O's strategy is to take advantage of opportunities while minimizing weaknesses. S-T Strategy is a strategy to optimize the strength to face challenges. W-T's strategy is to minimize the existing weaknesses and threats. 
The decision making stage is the stage where the business person starts to determine the best alternative strategy from the alternative strategies available at the matching stage. At this stage, a Quantitative Strategy Planning Matrix analysis tool is used. At this stage each factor is given an attractive score which indicates the relative attractiveness of each strategy to each factor. Total Attractive Score (TAS) for each strategy is obtained by multiplying the weight of each factor by the value of its attractiveness. The strategy with the biggest TAS is the most attractive strategy for the development of micro businesses in the Tomohon City culinary tourism area.

\section{RESULTS AND DISCUSSION}

\section{Entry Phase}

Internal factors that influence micro businesses in the culinary tourism area consist of strengths and weaknesses. The factors that become the strength of the micro business are as follows.

- Strategic business locations are locations located in the city center and adjacent to public facilities such as hospitals, shops, and several tourist attractions. Access to locations is very easy and can be reached by public transportation. This location provides adequate parking space and many people passing by at that location.

- Product diversity in terms of type, taste, and quantity gives consumers many choices to adjust to their needs so as to increase customer satisfaction and retention.

- The price of the product is relatively cheap so that it can be reached by all groups of people at all income levels. Low prices make consumers not worry about making regular repurchases even every day.

- To run a micro business does not require a large capital. Businesses have a small scale so that business owners can develop businesses without the need for large capital.

- That the target market of microbusinesses is very broad and not segmented represents its own strengths. This situation can attract more consumers to increase the number of sales and profits.

The factors that are the weaknesses of micro businesses in the culinary tourism area are as follows.

- Micro-businesses have uncomfortable business conditions: very simple supporting facilities such as tables, chairs and trash cans. This is a weakness that must be corrected. If not, this condition can reduce the interest of consumers to shop at the place.

- Micro businesses pay less attention to product innovation. Most sellers do not innovate to produce new food products or drinks that are unique and different.

- Business owners lack managerial skills. As a result, they are difficult to read every market opportunity that exists, do not have a vision of their business going forward, cannot implement the right strategy to develop existing businesses, and cannot properly manage any available resources.

- Micro businesses do not have good business financial records. They do not separate the financial wealth of personal and business. As a result, they cannot control business finances and evaluate profits over time.

- Micro entrepreneurs do not have complete product marketing: they only depend on consumers who pass through that location. 
Priska Shirty T.M. \& Reynaldo C.A. / Micro Business Development Strategy to Optimize Business Locations Culinary Tourism Area / JEE, Vol. 7, No. 2, September 2019, pp 41-50

They have no effort to utilize digital marketing through existing social media such as Facebook and Instagram.

Table 1 shows that the biggest strength factor of the micro businesses in the culinary tourism area is the variety of products with a total score of 0.44 . The biggest weakness of micro businesses in these locations is managerial ability with a total score of 0.11 . Overall, the IFE matrix shows a total value of 2.31 . This means that small businesses still have an internal capability below the 2.50 average. External factors that influence micro business development in culinary tourism areas consist of opportunities and threats. The factors that become micro business opportunities are as follows.

- The development of Tomohon City is very rapid: development and improvement of infrastructure, population growth, and improvement of the regional economy. This condition provides a great opportunity for businesses to increase the number of potential consumers and ease of distribution of goods or logistics.
- The development of technology such as machinery, digital communication tools, various applications, as well as hardware or software can increase efficiency and effectiveness in running a business.

- Suppliers of large quantities of raw materials provide opportunities for them to increase their bargaining power. Suppliers get them lower prices by reducing production costs and maximizing profits.

- The government provides support in developing MSMEs in the City of Tomohon such as the location of culinary tourism areas as a place for sellers of processed food, facilities and training from the Office of Cooperatives and MSMEs of Tomohon City, ICSB institutions to assist the development of MSMEs in each city/district in Indonesia.

- Loans for small businesses with low interest, such as the People's Business Credit (KUR), are opportunities for small businesses to increase working capital. Large capital encourages them to develop businesses by increasing the quality and quantity of business.

Table 1 Matrix of IFE Micro Business in a Culinary Tourism Area

\begin{tabular}{|c|c|c|c|c|}
\hline No. & Key Internal Factors & Weight & Rating & $\begin{array}{l}\text { Weighted } \\
\text { Score }\end{array}$ \\
\hline \multicolumn{5}{|c|}{ Strengths } \\
\hline 1. & Strategic business location & 0.09 & 4 & 0.36 \\
\hline 2. & Product diversity & 0.11 & 4 & 0.44 \\
\hline 3. & Product prices are relatively cheap & 0.08 & 4 & 0.32 \\
\hline 4. & The capital needed is not large & 0.07 & 3 & 0.21 \\
\hline 5. & The target market is very broad & 0.08 & 3 & 0.24 \\
\hline \multicolumn{5}{|c|}{ Weaknesses } \\
\hline 1. & The condition of the place of business is less comfortable & 0.09 & 2 & 0.18 \\
\hline 2. & Lack of product innovation & 0.14 & 1 & 0.14 \\
\hline 3. & Owner managerial ability is still lacking & 0.11 & 1 & 0.11 \\
\hline 4. & There are no financial records & 0.08 & 2 & 0.16 \\
\hline 5. & Product marketing is still lacking & 0.15 & 1 & 0.15 \\
\hline Tota & Weighted Score & 1.00 & & 2.31 \\
\hline
\end{tabular}


The factors that pose a threat to micro businesses in the culinary tourism area are as follows.

- The community has a lifestyle and tastes in the culinary field which is very fast. This is a threat to business people if they do not adjust the situation and consumer demand. Business people must innovate continuously: follow existing developments to meet market demand so that they are no less competitive and bankrupt.

- Substitution goods are high because products are commonly found. As a result, many sellers both inside and outside the culinary tourism area sell similar products. As a result, they must compete with themselves.

- High prices of foodstuffs such as basic foods have high fluctuations. This condition is caused by seasons and weather. Religious and cultural celebrations pose a threat to all culinary ventures. This is because culinary businesses must adjust to the price of raw materials without having to increase the selling price of the product.
- New businesses are very easy to enter the location. As a result, they can sell at the location of culinary tourism areas. This condition resulted in high competition between existing sellers.

- The bargaining power of buyers is high because the products offered are similar so that buyers have a strong bargaining power because they have many options in making purchasing decisions.

Table 2 shows that the biggest opportunity for micro businesses in the culinary tourism area is the development of information technology with a total score of 0.28. Meanwhile, the biggest threat to businesses in these locations is a change in lifestyle and people's tastes with a total score of 0.36 . The total value of the overall EFE matrix is 2.24, which means that micro businesses in the culinary tourism area are below the 2.50 average in exploiting opportunities and overcoming threats.

Table 2 EFE Matrix for Micro Enterprises in the Culinary Tourism Area

\begin{tabular}{llccc}
\hline \multicolumn{1}{l}{ No. } & Key External Factors & Weight & Rating & $\begin{array}{c}\text { Weighted } \\
\text { Score }\end{array}$ \\
\hline $\begin{array}{l}\text { Opportunities } \\
\text { 1. } \quad \text { The rapid development of Tomohon City }\end{array}$ & 0.11 & 2 & 0.22 \\
\hline 2. $\quad$ The development of information technology & 0.14 & 2 & 0.28 \\
\hline 3. $\quad$ A large number of suppliers are available & 0.09 & 1 & 0.09 \\
\hline 4. $\quad$ Government support and assistance & 0.08 & 3 & 0.24 \\
\hline 5. $\quad$ There is credit for small businesses with low interest rates & 0.10 & 2 & 0.20 \\
\hline Threats & & & \\
\hline 1. $\quad$ Changes in lifestyle and people's tastes & 0.12 & 3 & 0.36 \\
\hline 2. $\quad$ High substitute goods & 0.10 & 3 & 0.30 \\
\hline 3. $\quad$ Fluctuations in raw material prices & 0.11 & 3 & 0.33 \\
\hline 4. $\quad$ There are no obstacles for new businesses to enter & 0.08 & 1 & 0.08 \\
\hline 5. Bargaining power of buyers is high & 0.07 & 2 & 0.14 \\
\hline Total Weighted Score & 1.00 & & 2.24 \\
\hline
\end{tabular}


Priska Shirty T.M. \& Reynaldo C.A. / Micro Business Development Strategy to Optimize Business Locations Culinary Tourism Area / JEE, Vol. 7, No. 2, September 2019, pp 41-50

Table 3 SWOT Matrix for Micro Business in Culinary Tourism Areas

\begin{tabular}{|c|c|c|}
\hline Internal & $\begin{array}{l}\text { Strengths } \\
\text { 1. Strategic business location } \\
\text { 2. Product diversity } \\
\text { 3. The price of the product is } \\
\text { relatively cheap } \\
\text { 4. The capital needed is not } \\
\text { large } \\
\text { 5. The target market is very } \\
\text { broad }\end{array}$ & $\begin{array}{l}\text { Weaknesses } \\
\text { 1. Comfortable } \\
\text { 2. Lack of product innovation } \\
\text { 3. Owner managerial ability is } \\
\text { still lacking } \\
\text { 4. There is no financial record } \\
\text { 5. Product marketing is still } \\
\text { lacking }\end{array}$ \\
\hline $\begin{array}{l}\text { Opportunities } \\
\text { 1. The development of } \\
\text { Tomohon City is very rapid } \\
\text { 2. Development of information } \\
\text { technology } \\
\text { 3. A large number of suppliers } \\
\text { are available } \\
\text { 4. Government support and } \\
\text { assistance } \\
\text { 5. There is credit for small } \\
\text { businesses with low interest }\end{array}$ & $\begin{array}{l}\text { S-O strategy } \\
\text { 1. Increase production capacity } \\
\text { to meet consumer demand } \\
\text { (S2, S5, O1, O2, O5) } \\
\text { 2. Maintain an affordable } \\
\text { product price } \\
(\mathrm{S} 3, \mathrm{~S} 4, \mathrm{~S} 5, \mathrm{O} 3, \mathrm{O} 5)\end{array}$ & $\begin{array}{l}\text { W-O strategy } \\
\text { 1. Provide adequate supporting } \\
\text { facilities (W1, O1, O2, O4) } \\
\text { 2. Following management } \\
\text { training for business owners } \\
\text { (W3, O2, O4) } \\
\text { 3. Perform simple financial } \\
\text { records (W4, O2) } \\
\text { 4. Improve marketing especially } \\
\text { through digital marketing } \\
\text { (W5, O1, O2) }\end{array}$ \\
\hline $\begin{array}{l}\text { Threats } \\
\text { 1. Changes in people's lifestyles } \\
\text { and tastes } \\
\text { 2. Substitution goods are high } \\
\text { 3. Fluctuations in raw material } \\
\text { prices } \\
\text { 4. There are no obstacles for } \\
\text { new businesses to enter } \\
\text { 5. High bargaining power of } \\
\text { buyers }\end{array}$ & $\begin{array}{l}\text { S-T strategy } \\
\text { 1. Collaborating with suppliers } \\
\text { of raw materials (S1, S3, T2, } \\
\text { T3, T5) }\end{array}$ & $\begin{array}{l}\text { W-T strategy } \\
\text { 1. Improve product quality and } \\
\text { innovation (W2, T1, T2, T4, } \\
\text { T5) }\end{array}$ \\
\hline
\end{tabular}

\section{Matching Stage}

SWOT analysis is carried out to formulate alternative strategies that can be utilized to develop small businesses in the culinary tourism area. This is done by maximizing strengths and opportunities while minimizing weaknesses and threats as identified above. This SWOT analysis has produced four types of strategies, namely $S$ -

Table 4 QSPM Matrix of Micro Business in Culinary Tourism Areas

\begin{tabular}{clcc}
\hline No. & \multicolumn{1}{c}{ Priority Strategy } & TAS Scores & Rank \\
\hline $\mathbf{1}$ & Increase production capacity to meet consumer demand & 4.10 & VII \\
\hline $\mathbf{2}$ & Maintain affordable product prices & 4.85 & IV \\
\hline 3 & Provide adequate supporting facilities & 4.33 & VI \\
\hline 4 & Attends management training for business owners & 4.94 & III \\
\hline 5 & Perform simple financial records & 3.19 & VIII \\
\hline 6 & Increase marketing, especially through online marketing & 5.17 & II \\
\hline 7 & Cooperating with suppliers of raw materials & 4.49 & V \\
\hline 8 & Improve product quality and innovation & 5.74 & I \\
\hline
\end{tabular}


O (strengths-opportunities), W-O (weaknessesopportunities), S-T (strengths-threats), and W-T (weaknesses-threats) as shown in Table 3.

\section{Decision Making Stage}

Determination of the most attractive strategy for micro businesses in the culinary tourism area is produced using the Quantitative Strategy Planning Matrix (QSPM) analysis. This method produces priority strategies as described in Table 4.

The results of the analysis of the IFE matrix show that the greatest strength of micro businesses in the culinary tourism area is the variety of products due to diverse products both in terms of size, price, taste, appearance or other attributes that can meet the needs or desires of different consumers. Faradisa et al. (2016) prove that product variations can improve consumer purchasing decisions. The more variety of products offered, the higher the consumer's repurchase interest in the product.

The biggest weakness of micro businesses in the culinary tourism area is the managerial ability of business owners who are still lacking. They are not able to read market needs, implement appropriate business strategies, and follow existing developments. According to Cahyono \& Suhada (2016), lack of managerial skills can hamper the growth of MSMEs. This situation can cause problems in terms of the production cycle, product marketing, and other operational activities. Hajar et al. (2012) suggested that good managerial skills can improve business capabilities, competitive strategies, and business performance.

The results of the analysis of the external environment with the EFE matrix show that the biggest opportunity for micro businesses in the culinary tourism area is the development of information technology. Information technology can improve the efficiency and effectiveness of business processes. In this way, micro business people can optimize business activities and increase total revenue. Several studies suggest that information technology is needed in every business function both in production, distribution and marketing (Florida \& Hutabarat, 2015). Information technology can be used as a promotional tool. Because technology has a low cost, micro business people increase competitive advantage which results in increased sales and performance of SMEs (Adietya et al., 2016; Purwidiantoro et al., 2016).

The biggest threat to micro businesses in the culinary tourism area is changing lifestyles and people's tastes. The development of modern times also influenced the culinary trends. This triggers new culinary products and new business methods. This situation further increases competition among business actors. Several studies prove that lifestyle has a significant influence on consumer purchasing decisions on culinary products (Astuti, 2019; Nindyawati \& Iriani, 2014). MSMEs must innovate and be creative in developing their businesses, creating competitive advantages in the longer term so that they are able to compete and survive amid the changes.

The results of the IFE and EFE matrix analysis show numbers respectively 2.31 and 2.24 respectively below the average value of 2.50. Strategies that should be used in optimizing strengths and opportunities and minimizing weaknesses and threats are strategies related to market penetration and product development (David, 2011). For this reason, an appropriate alternative strategy for developing micro businesses in the culinary tourism area according to the SWOT matrix analysis is as follows. 


\section{S-O Strategy}

- Increase production capacity in order to offset the rapid population growth in Tomohon City and the broad target market by utilizing technology to accelerate production and availability of credit for small businesses as capital.

- Maintain affordable product prices to maintain customer purchase retention that can be done by increasing bargaining power towards suppliers.

- W-O strategy

- Provide adequate supporting facilities to increase comfort and add to the function and aesthetic value of the location provided so as to attract the attention of buyers.

- Participate in management training to gain more in-depth knowledge about business management including the resources that are owned so as to improve business performance and profitability.

- Perform simple financial records to determine the financial position and level of profitability of the business from time to time so that performance evaluations and preventive and corrective actions can be taken for business development.

- Increase product marketing by adding new promotional tools that take advantage of internet usage such as social media and other digital marketing.

- S-T Strategy

- Collaborating with suppliers of raw materials to get cheap prices and access to raw materials more quickly.

- W-T Strategy

- Improve product quality and innovation by creating new products that are in accordance with the times and existing market demands.
The QSPM analysis results show that the strategy that must be prioritized for the development of micro businesses in the culinary tourism area of the City of Tomohon is to improve the quality and product innovation with the highest total attractive value of 5.74. It is undeniable that the development of the times that lead to changes in lifestyle and people's tastes that are so fast requires every business including micro businesses to continue to innovate in meeting every changing market demand so that it can compete and not eroded by the times. Currently, businesses in the culinary tourism area have been trying to meet consumer demand by producing a variety of products both in terms of shape and taste. However, product innovation requires something new and different to produce competitive advantages that are not owned by competitors so that it can answer consumer demand, dominate the market, reduce bargaining power of buyers, and reduce buyer options for substitute goods. Bismala (2014) argues that product quality and innovation are business development strategies that are very important for all businesses including microbusinesses. This is because consumers always want products that provide added value and that are in accordance with their changing desires. Product quality and innovation can be done periodically by utilizing the development of information technology. Collaboration with government and private parties and academics needs to be done through technology transfer. Several previous studies confirm the same results: product quality and innovation have a positive effect on the competitive advantage of a business, and enhance the company's image, attract consumers, expand new markets, increase satisfaction and maintain customer loyalty (Dewi et al., 2012, Djodjobo \& Tawas, 2014). 
This research suggests that micro businesses in the culinary tourism area can improve the quality of their products and produce more innovative products. This strategy is expected to make businesses create products with uniqueness, competitiveness, and competitive advantage. This research is also expected to be useful for the government and related institutions in developing micro businesses in Tomohon City while optimizing the existence and function of the Tomohon City culinary tourism location. This research is limited to micro businesses engaged in culinary business with business owners as informants. It is hoped that further research can reach micro businesses in other fields to broaden the scope of research and involve customers as informants to obtain a more comprehensive and customer-oriented development strategy.

\section{REFERENCES}

Adietya, K., Miyasto, \& Sugiarto, Y. Analisis pengaruh teknologi informasi dan inovasi terhadap keunggulan bersaing untuk meningkatkan kinerja organisasi: Studi pada UKM makanan di Kota Semarang (Doctoral dissertation, Universitas Diponegoro). Retrieved from eprints.undip.ac.id.

Astuti, T. Y. (2019). Pengaruh suasana toko, gaya hidup, kemasan produk, dan inovasi produk terhadap keputusan pembelian konsumen: survei pada Kafe Kebun Roti Jalan Bugenville No. 1, Sleman, Yogyakarta (Doctoral dissertation, Universitas Pembangunan Nasional Veteran Yogyakarta). Retrieved from eprints.upnyk.ac.id.

Badan Ekonomi Kreatif Indonesia. (2017). Data statistik dan hasil survei ekonomi kreatif. Retrieved from https://www.bekraf.go.id/ pustaka/page/data-statistik-dan-hasilsurvei-khusus-ekonomi-kreatif.

Bismala, L. (2014). Analisis strategi pemasaran pada UMKM di Sumatera Utara untuk meningkatkan daya saing UMKM. Jurnal Pembangunan Perkotaan, 2(2). 126-134.

Cahyono, K., \& Suhada, B. (2016). Pengaruh pemberian kredit, kemampuan manajerial dan diferensiasi produk terhadap kinerja UMKM di Kota Metro. Derivatif 10(1), 1-9.

David, F. R. (2011). Strategic management: Concepts and cases (13 $3^{\text {th }}$ ed.). Upper Saddle River, NJ: Prentice Hall.

Dewi, N. K., Andri, G., \& Yonaldi, S. (2012). Pengaruh iklan, citra merek, dan kepuasan konsumen terhadap loyalitas konsumen dalam menggunakan Vaseline Hand and Body Lotion di Kota Padang (Studi Kasus di PT. Unilever Cabang Padang). Jurnal Manajemen dan Kewirausahaan, 3(2), 11-29.

Djodjobo, C. V., \& Tawas, H. N. (2014). Pengaruh orientasi kewirausahaan, inovasi produk, dan keunggulan bersaing terhadap kinerja pemasaran usaha nasi kuning di Kota Manado. Jurnal EMBA 2(3), 12141224.

Faradisa, I., Budi, L. H., \& Minarsih, M. M. (2016). Analisis pengaruh variasi produk, fasilitas, dan kualitas pelayanan terhadap minat beli ulang konsumen pada Indonesia Coffeeshop Semarang (Icos Café). Journal of Management 2(2). 01-13.

Florida, L. R., \& Hutabarat, W. M. (2015). Strategi pengembangan usaha kuliner di Kota Malang berbasis ekonomi kreatif. Jurnal Ekonomi dan Studi Pembangunan, 7(1), 12-20.

Hajar, I., Idrus, M. S., Salim, U., \& Solimun. (2012). Pengaruh kemampuan majerial dan 
Priska Shirty T.M. \& Reynaldo C.A. / Micro Business Development Strategy to Optimize Business Locations Culinary

Tourism Area / JEE, Vol. 7, No. 2, September 2019, pp 41-50

lingkungan industry terhadap kemampuan organisasi, strategi bersaing, dan kinerja perusahaan: studi pada industry kecil meube kayu di Sullawesi Tenggara. Jurnal Aplikasi Manajemen 10(21), 291-302.

Kementerian Koperasi dan UMKM. (2013). Perkembangan data Usaha Mikro, Kecil, Menengah (UMKM) dan Usaha Besar (UB) tahun 2012-2013. Retrieved from http:// www.depkop.go.id/uploads/tx_rtgfiles/ sandingan_data_umkm_2012-2013.pdf.
Nindyawati, V., \& Iriani, S. S. (2014). Pengaruh gaya hidup dan diferensiasi produk terhadap keputusan pembelian. Jurnal Ilmu Manajemen, 2(4), 1593-1605.

Purwidiantoro, M. H., Kristanto, D. F., \& Hadi W. (2016). Pengaruh penggunaan media sosial terhadap pengembangan usaha kecil menengah (UKM). Jurnal Eka Cida 1(1), 30-39. 